\title{
Genetic Transformation of Iris germanica Mediated by Agrobacterium tumefaciens
}

\author{
Zoran Jeknic, ${ }^{1}$ Stephen P. Lee, ${ }^{2}$ Joel Davis, ${ }^{1}$ Richard C. Ernst, ${ }^{3}$ and Tony H.H. Chen ${ }^{4}$ \\ Department of Horticulture, ALS 4017, Oregon State University, Corvallis, OR 97331
}

\begin{abstract}
AdDitional INDEX wORDs. bearded iris, genetic engineering, plant regeneration, transgenic plants
Abstract. A protocol was developed for production of transgenic iris plants (Iris germanica L. 'Skating Party') from regenerable suspension cultures via Agrobacterium-mediated transformation. We tested a series of selection agents, and identified hygromycin and geneticin as the most suitable for selecting transformed iris cells. Suspension cultures of iris were cocultured for 3 days with $A$. tumefaciens LBA 4404(pTOK233) carrying an intron-interrupted uidA (GUS) gene encoding $\beta$-glucuronidase, and hpt (hygromycin) and nptII (geneticin) selectable marker genes. Hygromycin- or geneticin-resistant calli having GUS enzyme activity were identified and used to induce plant regeneration. More than 300 morphologically normal transgenic iris plants were obtained in $\approx 6$ months. About $80 \%$ of the transformants were GUS-positive and NPTIIpositive (paromomycin-resistant). Integration of transgenes into the nuclear genome of iris plants was confirmed by Southern blot analysis. We have, therefore, developed an efficient $A$. tumefaciens-mediated transformation system for Iris germanica, which will allow future improvement of this horticulturally important ornamental monocot via genetic engineering.
\end{abstract}

Iris germanica is one of the most horticulturally important tall, bearded irises (Waddick and Zhao, 1992). Hundreds of valuable cultivars of this species have been developed and cultivated commercially as perennial ornamental plants. In addition to their ornamental value, rhizomes of some I. germanica cultivars contain an essential oil composed partly of irones (Jéhan et al., 1994; Kohlein, 1987). These violet-scented ketonic compounds are expensive materials commonly used in cosmetics and perfumes (Gozu et al., 1993).

Strong consumer demand means increased challenges in developing new iris cultivars with novel characteristics. Unfortunately, most efforts in iris breeding have been primarily intraspecific because of the high degree of incompatibility between species. Thus, the search for an alternative breeding method is imperative. Genetic transformation offers an alternative approach for introducing desirable traits, such as resistance to herbicides, diseases, and insects; or developing new floral colors (van Marrewijk, 1994).

Plant regeneration from somatic tissues is generally considered a prerequisite for genetic transformation. Unfortunately, low efficiency of plant regeneration in I. germanica and other Iris species has hindered development of a suitable transformation system. We recently established a stable suspension culture of Iris germanica 'Skating Party' and developed an efficient system for plant regeneration (Wang et al. 1999a, 1999b).

Three major approaches for plant transformation include Agrobacterium tumefaciens-mediated transformation, microprojectile bombardment (biolistic method), and direct gene transfer to protoplasts (electroporation and polyethylene glycol-mediated transfor-

Received for publication 4 Jan. 1999. Accepted for publication 18 Aug. 1999 Oregon Agricultural Experiment Station technical paper no. 11467. We thank Barbara M. Reed and William M. Proebsting for their helpful reviews. Agrobacterium tumefaciens LBA4404(pTOK233) used in this project was obtained through a research agreement with Japan Tobacco, Inc., Shizuoka 438, Japan. The gift of Claforan from Doug Morrow, Hoechet-Roussel Pharmaceuticals, Inc., Somerville, NJ 08876, is gratefully acknowledged. The cost of publishing this paper was defrayed in part by the payment of page charges. Under postal regulations, this paper therefore must be hereby marked advertisement solely to indicate this fact.

${ }^{1}$ Faculty research assistant

${ }^{2}$ Assistant professor, Department of Biological Sciences, Simon Fraser University, Burnaby, B.C., Canada V5A 1A6.

${ }^{3}$ President and General Manager, Cooley's Gardens, P.O. Box 126, Silverton, OR 97381.

${ }^{4}$ Professor and corresponding author; e-mail; chent@bcc.orst.edu. mation). Microprojectile bombardment and direct gene transfer to protoplasts are used commonly to transform a variety of monocotyledonous plants (Vain et al., 1995). However, stable (integrative) transformation of only two horticulturally important ornamental monocots, Dendrobium Swartz orchid (Kuehnle and Sugii, 1992) and Gladiolus L. (Kamo et al., 1995), by microprojectile bombardment have been reported.

Agrobacterium-mediated transformation has significant advantages over other approaches such as integrating a few copies of TDNA with defined border sequences and minimal rearrangement in the plant genome, preferential integration into transcriptionally active regions of the chromosome, high quality and fertility of resultant transgenic plants, and easy manipulation (Komari et al., 1998; Tingay et al., 1997).

Methods for transforming dicotyledonous species with Agrobacterium are well established. In contrast, until recently monocotyledons were considered beyond the range of A. tumefaciens transformation methods. Various attempts to infect monocots with Agrobacterium were made in the 1970s and 1980s, but no conclusive evidence of integrative transformation was reported (Conner and Dommisse, 1992; Smith and Hood, 1995). Successful A. tumefaciens-mediated transformation, however, is now possible in several agronomically important monocots including corn (Zea mays L.), wheat (Triticum aestivum L.), rice (Oryza sativa L.), barley (Hordeum vulgare L.), and sugar cane (Saccharum spp. L.) (Arencibia et al., 1998; Cheng et al., 1997; Hiei et al., 1994; Ishida et al., 1996; Tingay et al., 1997). The utility of A. tumefaciens for stable (integrative) transformation of ornamental monocots was demonstrated only in Anthurium scherzerianum Schott 'Rudolph' and 'UH1060' (Chen and Kuehnle, 1996). We report here on the development of an efficient A. tumefaciens-mediated transformation method for Iris.

\section{Materials and Methods}

SUSPENSION CULTURES. Cell suspension cultures of Iris germanica 'Skating Party', capable of plant regeneration, were established in our laboratory (Wang et al., 1999a, 1999b). Cultures were maintained in MS-L medium [MS basal medium (Murashige and Skoog, 1962), containing $50 \mathrm{~g} \cdot \mathrm{L}^{-1}$ sucrose, $290 \mathrm{mg} \cdot \mathrm{L}^{-1}$ proline, $0.5 \mu \mathrm{M}$ kinetin (Kin), and 5.0 $\mu_{\mathrm{M}}$ 2,4-dichlorophenoxyacetic acid (2,4-D); pH5.9 (Wang et al., 1999a, 1999b)] in the dark at $25^{\circ} \mathrm{C}$ on a gyratory 
shaker (120 rpm), and were subcultured every 3 to 4 weeks.

Evaluation OF SElection agents. There is no information available on agents that are suitable for selection of stable iris transformants. To determine the efficacy of several commonly used agents for selecting transformed iris cells, we tested five antibiotics: methotrexate, hygromycin, geneticin (G418), gentamycin, and phleomycin; three herbicides: glyphosate [N-(phosphonomethyl)glycine] (Monsanto, St. Louis, Mo.), chlorsulfuron [2chloro-N-[[(methoxy-6-methyl-,3,5-triazin-2-yl)amino] carbonyl] benzenesulfonamide] (E.I. Du Pont de Nemours \& Co., Inc., Agricultural Products Dept., Wilmington, Del.) and glufosinateammonium (Basta; Hoechst Canada, Inc., Regina, Saskatchewan, Canada); and one amino acid analog (4-methyl-tryptophane) (Sigma Chemical Co., St. Louis, Mo.). These agents were chosen because genes conferring resistance to those compounds have been cloned (reviewed by Schrott, 1995). The efficacy of each selection agent was evaluated by its ability to suppress growth of nontransformed iris cells on media containing increasing levels of the selection agent.

The liquid MS-L medium was removed from a 3-week-old iris suspension culture and the cells were spread on Whatman No. 1 filter papers $(42.5 \mathrm{~mm}$ diameter) in small culture plates $(60 \times 15$ $\mathrm{mm}$ ), over MS-C medium [MS-L medium with $3 \mathrm{~g} \cdot \mathrm{L}^{-1}$ Phytagel (Sigma) (Wang etal., 1999a, 1999b)] containing increasing amounts of the selection agent. Plates were incubated for 3 weeks in the dark at $25{ }^{\circ} \mathrm{C}$. In preliminary experiments, five concentrations of each selection agent were tested and inhibition of cell growth was scored visually. Among the nine compounds tested,4-methyl-tryptophane, gentamycin, phleomycin, and glyphosate did not clearly inhibit growth, and were excluded from further testing.

The five most effective selection agents from preliminary experiments were reassayed. This time, fresh weights were measured and mean values expressed as a percentage of growth by controls (no selection agent). At least five plates were used for each concentration of selection agent.

BACTERIAL STRAIN AND PLASMID VECTOR. In preliminary studies, three A. tumefaciens strains were tested to identify the one giving the highest transient transformation rates. The strains tested were: LBA 4404 (pTOK233), LBA4404(pCAMBIA1201), and EHA105 (pCAMBIA1201). The A. tumefaciens strain LBA4404 harboring the superbinary vector, pTOK233, was obtained from Japan Tobacco, Inc., Shizuoka, Japan (Hiei et al., 1994). pCAMBIA1201 binary vector (CAMBIA, Canberra City, Australia) was transformed into A. tumefaciens LBA4404 (Hoekema et al., 1983) and EHA105 (Hood et al., 1993) according to the procedure described by Walkerpeach and Velten (1994). All strains contained a hygromycin resistance gene (PCaMV35S-hpt-T35S) and an introninterrupted GUS gene (PCaMV35S-uidA-TNOS) within the TDNA borders. pTOK233 also contained a geneticin resistance gene (PNOS-nptII-TNOS). They were grown on solid $\mathrm{AB}$ medium (Chilton et al., 1974), containing appropriate antibiotics, at $28^{\circ} \mathrm{C}$ for $3 \mathrm{~d}$. The bacteria were harvested and resuspended in AAM medium (Hiei et al., 1994) to give an absorbance of $\approx 1.8$ at $600 \mathrm{~nm}$.

Transformation. Three-week-old iris suspension cultures grown in MS-L medium were used for transformation experiments. The MS-L medium was removed from the culture and A. tumefaciens suspension $(25 \mathrm{~mL})$ was added, the flask was gently shaken, and left to stand for $5 \mathrm{~min}$. The liquid phase was removed and cells were spread onto MS-C-AS medium (MS-C medium with $10 \mathrm{~g} \cdot \mathrm{L}^{-1}$ glucose, $100 \mu \mathrm{m}$ acetosyringone; $\mathrm{pH}$ 5.2), then incubated in the dark at $25^{\circ} \mathrm{C}$ for $3 \mathrm{~d}$.

Selection of transformants. After $3 \mathrm{~d}$ cocultivation, the cells were collected with a spatula and rinsed thoroughly with 250 $\mathrm{mg} \cdot \mathrm{L}^{-1}$ cefotaxime (Claforan; Hoechet-Roussel Pharmaceuticals, Inc., Somerville, N.J.) dissolved in sterile water. Half the washed cells were spread on MS-C medium containing $250 \mathrm{mg} \cdot \mathrm{L}^{-1}$ cefotaxime and $50 \mathrm{mg} \cdot \mathrm{L}^{-1}$ hygromycin, the other half on MS-C medium containing $250 \mathrm{mg} \cdot \mathrm{L}^{-1}$ cefotaxime and $50 \mathrm{mg} \cdot \mathrm{L}^{-1} \mathrm{G} 418$, then cultured in the dark at $25^{\circ} \mathrm{C}$ for 3 weeks. The cell clumps that proliferated on these selection media were transferred to the second selection media (MS-C containing $250 \mathrm{mg} \cdot \mathrm{L}^{-1}$ cefotaxime and either $100 \mathrm{mg} \cdot \mathrm{L}^{-1}$ hygromycin or $100 \mathrm{mg} \cdot \mathrm{L}^{-1} \mathrm{G} 418$ ) and cultured for another 3 weeks under the same conditi2ons.

The cell clumps that continued to grow on the second selection media were assayed for expression of the GUS gene as described below. Only those clumps that tested GUS-positive were transferred individually to small culture plates containing $10 \mathrm{~mL}$ MS-I media [MS basal medium (Murashige and Skoog, 1962), with $50 \mathrm{~g} \cdot \mathrm{L}^{-1}$ sucrose, $10 \mathrm{mg} \cdot \mathrm{L}^{-1}$ pantothenic acid, $4.5 \mathrm{mg} \cdot \mathrm{L}^{-1}$ niacin, $1.9 \mathrm{mg} \cdot \mathrm{L}^{-1}$ thiamin, $250 \mathrm{mg} \cdot \mathrm{L}^{-1}$ casein hydrolysate, $250 \mathrm{mg} \cdot \mathrm{L}^{-1}$ proline, $0.5 \mu \mathrm{M}$ 1-naphthaleneacetic acid (NAA), $12.5 \mu \mathrm{M}$ Kin, $2.0 \mathrm{~g} \cdot \mathrm{L}^{-1}$ Phytagel; pH5.7 (Wang etal., 1999a, 1999b)] containing $250 \mathrm{mg} \cdot \mathrm{L}^{-1}$ cefotaxime and either $50 \mathrm{mg} \cdot \mathrm{L}^{-1}$ hygromycin or $50 \mathrm{mg} \cdot \mathrm{L}^{-1} \mathrm{G} 418$ to induce plant regeneration. They were cultured in the dark at $25^{\circ} \mathrm{C}$ for 3 weeks. The cell clumps that displayed typical morphogenic changes were selected and transferred to MS-D medium [MS-I medium without NAA and Kin but supplemented with $1.25 \mu \mathrm{M}$ 6-benzyladenine (BA) (Wang et al., 1999a, 1999b)] containing $250 \mathrm{mg} \cdot \mathrm{L}^{-1}$ cefotaxime and either $50 \mathrm{mg} \cdot \mathrm{L}^{-1}$ hygromycin or $50 \mathrm{mg} \cdot \mathrm{L}^{-1} \mathrm{G} 418$, in Magenta GA-7 vessels (Sigma) and cultured for 2 to 3 weeks at $23^{\circ} \mathrm{C}$ with a $16 \mathrm{~h}$ photoperiod of $50 \mu \mathrm{mol} \cdot \mathrm{m}^{-2} \cdot \mathrm{s}^{-1}$ provided by cool-white fluorescent lamps. Irradiance was measured on the tops of Magenta GA-7 vessels with a quantum-radiometer-photometer (LI-189; LICOR, Inc., Lincoln, Nebr.).

Shoots and plantlets (rooted shoots) were transferred to MS-D medium without selection agents to facilitate growth and development for another 2 to 3 weeks. Both shoots and plantlets were then transferred to MS-R medium [MS-I medium without NAA and Kin (Wang et al., 1999a, 1999b)] in Magenta GA-7 vessels for root induction and development. They were subcultured every other week on this medium.

Well-rooted plantlets ( 4 to $6 \mathrm{~cm}$ shoot length) were transferred to a growing medium 3 peat : 2 pumice : 1 sandy loam (v/v) in $250-\mathrm{mL}$ pots and acclimatized on a mist bench (relative humidity $=95 \%$ to $98 \%$ ) in a greenhouse maintained at $16 \mathrm{~h}$ days $/ 8 \mathrm{~h}$ nights of 25 $\pm 3 / 20 \pm 3{ }^{\circ} \mathrm{C}$ with a $16 \mathrm{~h}$ photoperiod. Light was supplemented by high-pressure sodium lamps (Energy Technics, York, Pa.) providing photosynthetically active radiation $(P A R)$ of 400 to 500 $\mu \mathrm{mol} \cdot \mathrm{m}^{-2} \cdot \mathrm{s}^{-1}$ at the surface of growing medium. Four to five weeks later the plants were moved to a nonmisted bench and fertilized with a controlled-release fertilize [Nutricot-Type $100(16 \mathrm{~N}-4.4 \mathrm{P}-8.3 \mathrm{~K})$; Chisso-Asahi,, Fertilizer Co., Ltd., Tokyo, Japan).

Assay For gus aCtivity. To determine transient transformation rates, a few cells were collected with a spatula $3 \mathrm{~d}$ after cocultivation with A. tumefaciens, and washed thoroughly with a $0.1 \mathrm{M}$ sodiumphosphate buffer ( $\mathrm{pH}$ 7.2) to remove surface bacteria. Cells were spread on filter paper in a small culture plate and $1 \mathrm{~mL}$ of the GUSstaining solution $[0.1 \mathrm{~m}$ sodium phosphate buffer $\mathrm{pH} 7.2,5 \mathrm{~mm}$ $\mathrm{K}_{3}\left[\mathrm{Fe}(\mathrm{CN})_{6}\right], 5 \mathrm{~mm} \mathrm{~K}_{4}\left[\mathrm{Fe}(\mathrm{CN})_{6}\right], 10$ mm EDTA, 20\% methanol (v/ $\mathrm{v}), 0.01 \%$ Triton $\mathrm{X}-100(\mathrm{v} / \mathrm{v})$, and $1 \mathrm{mg} \cdot \mathrm{mL}^{-1}$ 5-bromo-4-chloro-3indolyl glucuronide] was added. Plate was then sealed with Parafilm and incubated overnight at $37^{\circ} \mathrm{C}$.

To identify GUS-positive cell clumps from the second selection media, a small piece ( 3 to $4 \mathrm{~mm}$ diameter) of each clump was placed 

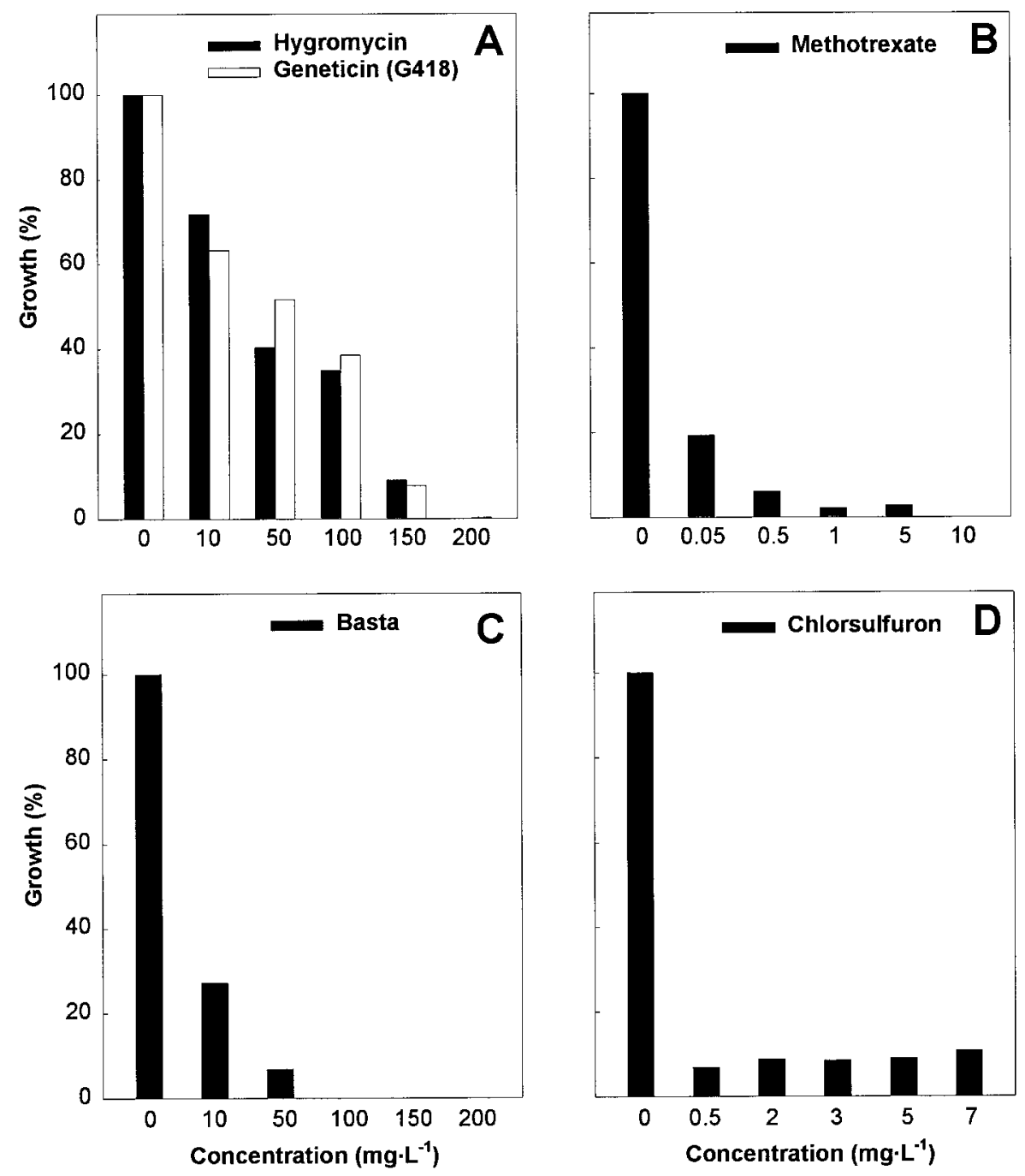

solution containing $25 \mathrm{mg} \cdot \mathrm{L}^{-1}$ benomyl fungicide [methyl 1-(butylcarbamoyl)-2 benzimidazolecarbamate] (Hi-Yield Chem. Co., Bonham, Texas) and $0.01 \%$ Triton X-100 (Sigma), in 24-well culture plates, as a control. Each of the remaining three pieces were placed in $1 \mathrm{~mL}$ of the same solution with either 50,100 , or $200 \mathrm{mg} \cdot \mathrm{L}^{-1}$ paromomycin (Sigma). Leaf samples from the nontransformed iris plants at a similar developmental stage were used as a negative control. The samples were vacuum-infiltrated for $10 \mathrm{~min}$. The plates were then sealed with Parafilm and incubated for $5 \mathrm{~d}$ at $23^{\circ} \mathrm{C}$ with a $16 \mathrm{~h}$ photoperiod of 50 $\mu \mathrm{mol} \cdot \mathrm{m}^{-2} \cdot \mathrm{s}^{-1}$ provided by cool-white fluorescent lamps. In preliminary assays we also tested G418 and hygromycin, the latter one for the functional expression of the $h p t$ gene. The response to all three antibiotics was very similar (data not shown), so we chose paromomycin to assay the rest of the putative transgenic iris plants because it was least expensive.

DNA ISOLATION AND SOUTHERN HYBRIDIZATIONANALYSIS. DNA was extracted from $4 \mathrm{~g}$ of young leaves using the protocol of Rawson et al. (1982) modified by Davis et al. (1998). The leaf tissue was homogenized in $40 \mathrm{~mL}$ grinding buffer (100 mm Tris, $25 \mathrm{~mm}$ EDTA, 0.35 M sucrose, $50 \mathrm{~mm} \mathrm{KCl}, 5 \%$ polyvinylpyrrolidone, $10 \mathrm{~mm}$ diethyldithiocarbamic acid, and $0.2 \%$ mercaptoethanol), using a Waring 250 $\mathrm{mL}$ stainless steel blender for $15 \mathrm{~s}$. The homogenate was filtered through cheesecloth and centrifuged at $12,000 g_{\mathrm{n}}$ for $20 \min \left(4^{\circ} \mathrm{C}\right)$.

The pellet was resuspended in $6 \mathrm{~mL}$ lysis buffer (100 mm EDTA; 50 mm Tris-HCl, $\mathrm{pH}$

Fig. 1. Effect of three antibiotics [(A) hygromycin and geneticin (G418), and (B) methotrexate] and two herbicides [(C) Basta and (D) chlorsulfuron] on growth of nontransformed iris suspension-cultured cells. Each data point represents at least five replicates.

on filter paper in small culture plates. One milliliter of staining solution was added to each plate; then the plates were sealed with Parafilm and incubated overnight at $37^{\circ} \mathrm{C}$.

Regenerated structures (globular embryo-like structures and shoot primordia) were excised and stained for GUS activity in 100 $\mu \mathrm{L}$ staining solution in microcentrifuge tubes. The samples were infiltrated with staining solution under vacuum for $10 \mathrm{~min}$ and incubated overnight at $37^{\circ} \mathrm{C}$.

Slices of green leaves (2-mm) and roots $(5-\mathrm{mm})$ were placed in microcentrifuge tubes with $100 \mu \mathrm{L}$ of staining solution. They were infiltrated with staining solution under vacuum for $10 \mathrm{~min}$ and stained overnight at $37^{\circ} \mathrm{C}$. Chlorophyll from green leaves was bleached out with several changes of $95 \%$ ethanol before results were scored.

FunCTIONAL ASSAY OF NPTII GENES. To test the NPT II expression in transformed iris plants, the leaf-bleach assay was carried out according to Cheng et al. (1997), with minor modifications described below. Four pieces $(\approx 7 \mathrm{~mm})$ were cut from the second youngest leaf of each plant $\approx 1$ month after establishment in growing medium in the greenhouse. One leaf piece was placed in $1 \mathrm{~mL}$ of incubated at $37^{\circ} \mathrm{C}$ in a shaking incubator for $2 \mathrm{~h}$. The lysate was then centrifuged at $15,000 \mathrm{~g}_{\mathrm{n}}$ for $10 \mathrm{~min}\left(4^{\circ} \mathrm{C}\right)$, and the supernatant was precipitated with $2 / 3$ volume isopropanol at $-20^{\circ} \mathrm{C}$ for $30 \mathrm{~min}$. The precipitate was pelleted at $20,000 g_{\mathrm{n}}$ for $15 \mathrm{~min}$ at $4^{\circ} \mathrm{C}$. Afterward, the pellet was resuspended in TE buffer (10 mM Tris- $\mathrm{HCl}, 1 \mathrm{~mm}$ EDTA; $\mathrm{pH}$ 8.0) and the DNA was purified further through a $\mathrm{CsCl}$ gradient as described by Rawson et al. (1982). The DNA sample was precipitated, washed with $70 \%$ ethanol, and resuspended in TE buffer at a concentration of $1 \mu \mathrm{g} \cdot \mu \mathrm{L}^{-1}$.

Southern blot analysis was performed as described by Sambrook et al. (1989). Briefly, the method involved digesting $20 \mathrm{mg}$ genomic DNA with HindIII, resolving on a $0.8 \%$ agarose gel, then blotting onto a nylon membrane (Zetaprobe, Bio-Rad, Richmond, Calif.). Identically prepared blots were probed with radiolabelled GUS or hpt DNA fragments. A 250-bp fragment in the GUS coding region and a $608 \mathrm{bp}$ fragment in the $h p t$ coding region were PCR-amplified according to Gould et al. (1991) and Abedinia et al. (1997), respectively. PCR-amplified fragments were labelled with $\left[{ }^{32} \mathrm{P}\right] \mathrm{dCTP}$ by random priming (Feinberg and Vogelstein, 1983) and used as probes. The blots were first washed at low stringency $(2 \times \mathrm{SSC}, 0.1 \% \mathrm{SDS})$ twice at $65^{\circ} \mathrm{C}(30 \mathrm{~min}$ each) followed by two washes ( $30 \mathrm{~min}$ each) at moderate stringency $(0.5 \times \mathrm{SSC}, 0.1 \% \mathrm{SDS})$ at $65^{\circ} \mathrm{C}$. Blots were autoradiographed with an intensifying screen at $-85^{\circ} \mathrm{C}$ for $5 \mathrm{~d}$.
$8.0 ; 2.5 \%$ Triton X-100; $2 \%$ sarkosyl; $50 \mu \mathrm{g} \cdot \mathrm{mL}^{-1}$ Proteinase $\mathrm{K}$ ) and 


\section{Results and Discussion}

EVALUATION OF SELECTION AGENTS. Increasing the concentration of hygromycin and geneticin (G418) resulted in a gradual decrease in the percentage of iris cell growth. We chose to use hygromycin and geneticin separately for our transformation experiments because pTOK233 contains both $h p t$ and $n p t I I$ selectable marker genes for plant cells, rendering them resistant to either hygromycin or geneticin. Both hygromycin and geneticin at concentrations of 50 to $100 \mathrm{mg} \cdot \mathrm{L}^{-1}$ caused $40 \%$ to $50 \%$ growth inhibition (Fig. 1A). We chose to apply a two-step selection, first $50 \mathrm{mg} \cdot \mathrm{L}^{-1}$ and then 100 $\mathrm{mg} \cdot \mathrm{L}^{-1}$ for both selection agents. The two-step selection $(3+3$ weeks) allowed recovery of a large enough mass of each independent callus line for efficient induction of multiple shoots in subsequent regeneration experiments. Higher concentrations of either antibiotic were not used because there was the possibility of inhibiting plant regeneration from transgenic callus tissue.

Cell growth, however, was greatly inhibited at $0.05 \mathrm{mg} \cdot \mathrm{L}^{-1}$ methotrexate $(\approx 80 \%), 10 \mathrm{mg} \cdot \mathrm{L}^{-1}$ Basta $(\approx 70 \%)$, and $0.5 \mathrm{mg} \cdot \mathrm{L}^{-1}$ chlorsulfuron $(\approx 90 \%)$ (Fig. $1 \mathrm{~B}, \mathrm{C}$, and D). In a preliminary study on the use of microparticle bombardment for iris transformation, transgenic calli selected on $10 \mathrm{mg} \cdot \mathrm{L}^{-1}$ Basta showed very low regeneration potential (Jeknic and Chen, unpublished results).

TraNSFORMATION AND REGENERATION OF TRANSGENIC IRIS PLANTS. Agrobacterium strainLBA4404(pTOK233) gave remarkably higher transient transformation rates than eitherLBA4404(pCAMBIA1201) or EHA105(pCAMBIA1201) (data not shown), and was therefore used for the stable transformation experiments. This plasmid belongs to a class called superbinary vectors because it carries the virB,

$\operatorname{vir} C$, and virG genes of A281, a highly efficient strain for transforming higher plants (Komari, 1990). Introduction of a DNA fragment from the virulence region of Ti-plasmid into a binary vector or into a separate plasmid has been shown to lead to the increased virulence of A. tumefaciens and much higher transformation rates in several plant species (Arias-Garzón and Sarria, 1995; Hiei et al., 1994; Li et al., 1996; Liu et al., 1992; Wenck et al., 1999).

After $3 \mathrm{~d}$ cocultivation on MS-C-AS medium with A. tumefaciens, the infected cells were transferred to the first two selection media (MS-C containing $250 \mathrm{mg} \cdot \mathrm{L}^{-1}$ cefotaxime and either $50 \mathrm{mg} \cdot \mathrm{L}^{-1}$ hygromycin or $\left.50 \mathrm{mg} \cdot \mathrm{L}^{-1} \mathrm{G} 418\right)$. At that time a sample of cells was stained for expression of the GUS gene. Many cells and small cell aggregates stained dark blue (Fig. 2A), confirming that T-DNA transfer occurred. GUS expression most likely occurred in the transformed cells and not in pTOK233-containing Agrobacterium because the presence of an intron in the GUS coding region efficiently prevented its expression in bacterial cells (Ohta etal., 1990). After $10 \mathrm{~d}$, several of the cell clumps that proliferated on the first selection media (Fig. 2B) were stained for GUS activity. Most clumps were stained uniformly dark blue (Fig. 2C), but some clumps also contained unstained patches.

After 3 weeks on the first two selection media, $\approx 300$ independent clumps were selected from each medium and transferred to the second two selection media, which contained an increased concentration of selection agents. Most calli transferred to a medium containing G418 continued to grow much more slowly than those transferred to a medium containing hygromycin. The slower growth of transformed callus tissue on G418-containing media may be due, at least in part, to the difference in promoter strength. In pTOK233, the hpt and nptII genes are driven by CaMV35S and NOS promoters, respectively. In our preliminary experiments using microprojectile bombardment, we found that

Fig. 2. Transient expression of the GUS gene in A.tumefaciens-infected suspensioncultured iris cells, stable GUS expression in various tissues from transgenic plants, and steps in the regeneration of transgenic plants. (A) assay for expression of the GUS gene immediately after 3 d cocultivation. Many iris cells and small aggregates were stained dark blue. (B) a cell clump that proliferated on the first selection media $10 \mathrm{~d}$ after cocultivation. (C) the majority of clumps that proliferated on the first selection media tested GUS-positive. Most of clumps were stained dark blue indicating very strong expression of the GUS gene. (D) independent callus lines obtained through two-step selection were assayed for expression of the GUS gene before transfer to shoot induction media(MS-I).(E) hygromycin-resistant, GUS-positive callus line with numerous shoot primordia present after 3 weeks on the MS-I medium. (F) a number of the shoot primordia were excised and stained for the expression of the GUS gene. Most of them tested GUS-positive. (G) plantlets with well-developed shoots and roots after 4 weeks on the MS-R medium. (H) transgenic plants in the greenhouse 1 week after acclimatization on the mist bench. (I) assay for the functional expression of NPTII gene (leaf-bleach assay). 0, 50, 100, and $200=0,50,100$, and 200 $\mathrm{mg} \cdot \mathrm{L}^{-1}$ paromomycin, respectively; $\mathrm{WT}=$ wild type (nontransformed) plant; L1, L2, and L3 = leaf samples from three independent transformants. (J) and (K) GUS expression in leaf tissue from a greenhouse-grown transgenic plant; surface and cross-section, respectively. (L) GUS expression in root tissue of a young, in vitro-grown transgenic plant.
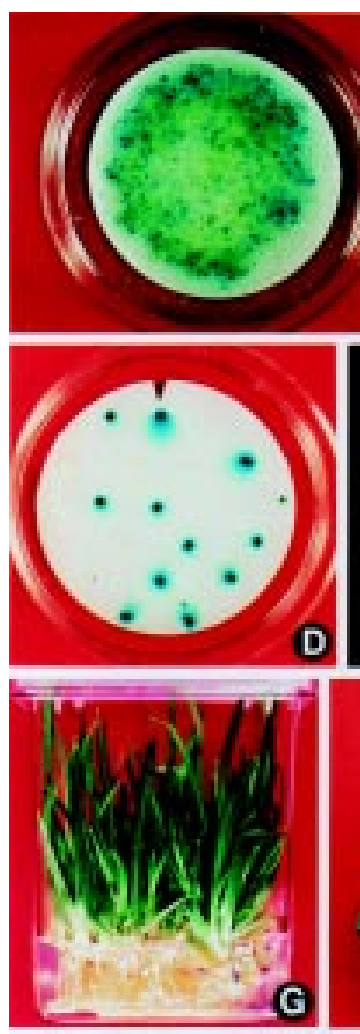

。
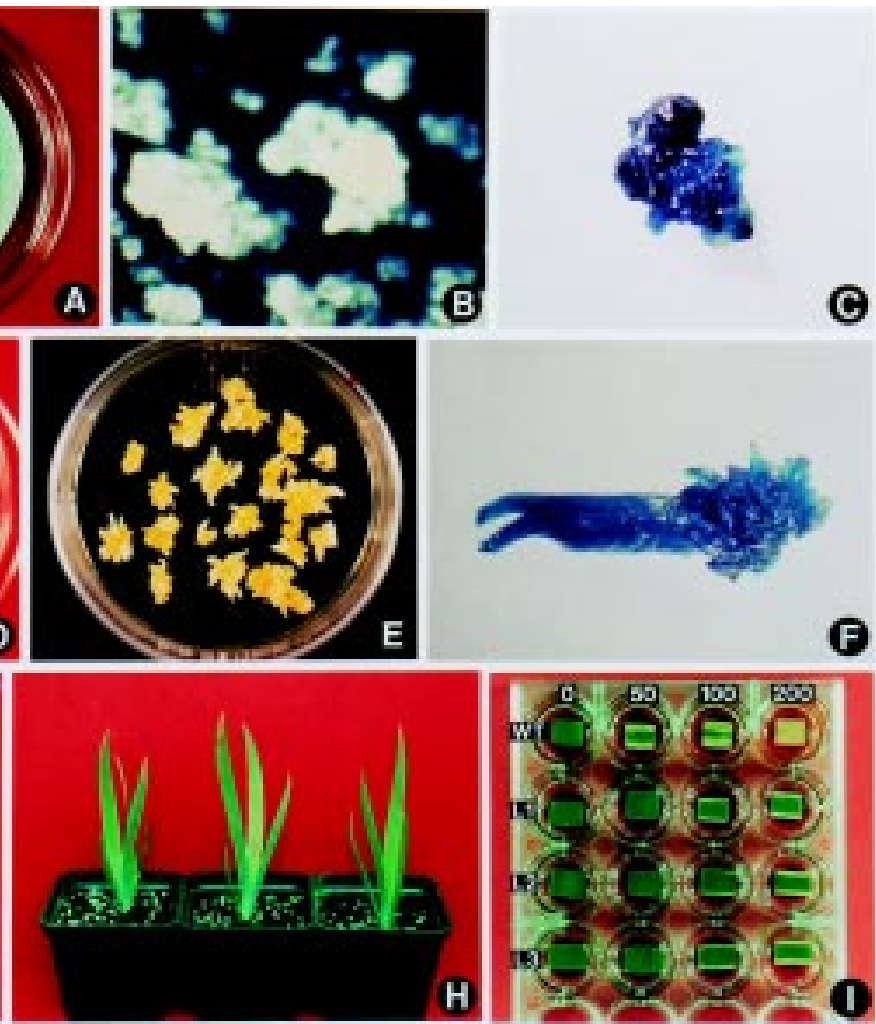

H
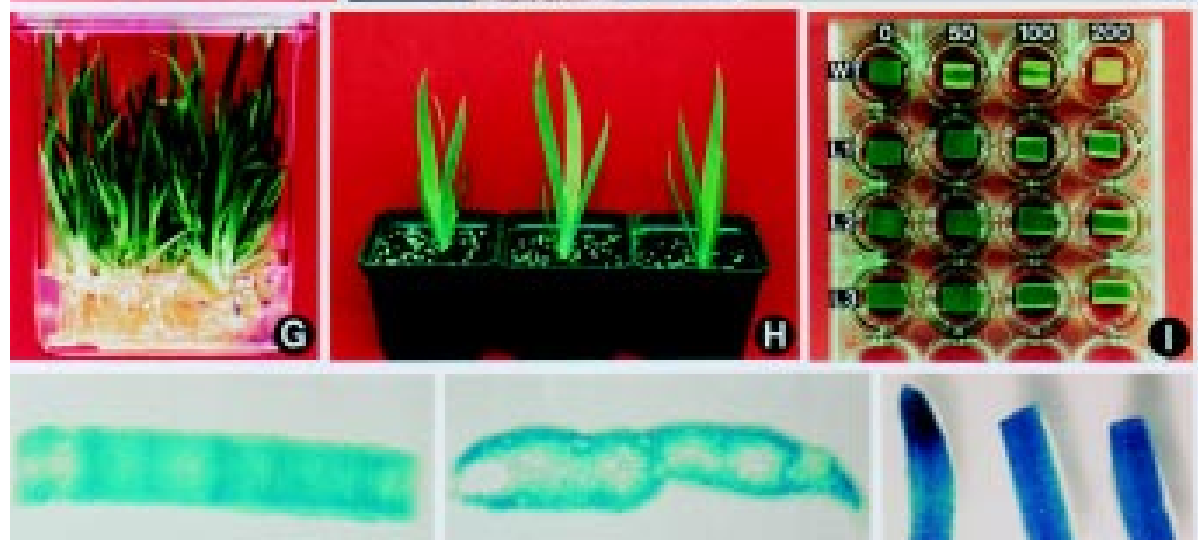

()

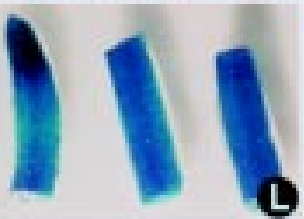


Table 1. Expression of the GUS and NPTII genes in hygromycin (Hyg) and geneticin (G418) resistant Iris plants as determined by the histochemical staining and the leaf-bleach assay, respectively.

\begin{tabular}{|c|c|c|c|c|c|c|c|c|c|c|c|}
\hline \multirow[b]{2}{*}{$\begin{array}{l}\text { Selection } \\
\text { agent }\end{array}$} & \multicolumn{3}{|c|}{ GUS } & \multicolumn{3}{|c|}{ NPTII } & \multicolumn{5}{|c|}{ Coexpression of GUS and NPTII } \\
\hline & $\begin{array}{c}\text { No. plants } \\
\text { (lines) } \\
\text { assayed }\end{array}$ & $\mathrm{GUS}^{+}$ & $\mathrm{GUS}^{-}$ & $\begin{array}{c}\text { No. Plants } \\
\text { (lines) } \\
\text { assayed }\end{array}$ & $\mathrm{NPTII}^{+}$ & $\mathrm{NPTII}^{-}$ & $\begin{array}{c}\text { No. plants } \\
\text { (lines) } \\
\text { assayed }\end{array}$ & $\begin{array}{c}\mathrm{GUS}^{+} \\
\mathrm{NPTII}^{+}\end{array}$ & $\begin{array}{c}\mathrm{GUS}^{+} \\
\mathrm{NPTII}^{-}\end{array}$ & $\begin{array}{c}\mathrm{GUS}^{-} \\
\mathrm{NPTII}^{+}\end{array}$ & $\begin{array}{c}\text { GUS }^{-} \\
\text {NPTII }^{-}\end{array}$ \\
\hline Hyg & $72(30)$ & 61 & 11 & $51(27)$ & 45 & 6 & $50(23)$ & 40 & 1 & 4 & 5 \\
\hline G418 & $20(6)$ & 13 & 7 & $9(6)$ & 6 & 3 & $8(3)$ & 5 & 0 & 0 & 3 \\
\hline Total & $92(36)$ & 74 & 18 & $60(33)$ & 51 & 9 & $58(26)$ & 45 & 1 & 4 & 8 \\
\hline Percent & & 80 & 20 & & 85 & 15 & & 78 & 2 & 7 & 14 \\
\hline
\end{tabular}

transient expression of PCaMV35S-uidA-TNOS was much higher than that of PNOS-uidA-TNOS (Jeknic and Chen, unpublished results).

Independent callus lines obtained through the two-step selection (175-hygromycin resistant, 50-G418 resistant) were then assayed for expression of GUS. About $61 \%$ of hygromycin-resistant and $46 \%$ of the G418-resistant callus lines tested GUS-positive. After overnight incubation in the GUS-staining solution, most of the GUS-positive cell clumps were stained dark blue, indicating very strong expression of the GUS gene (Fig. 2D). All callus lines that tested GUS-negative were discarded; only GUS-positive lines were transferred to MS-I media to induce plant regeneration. A total of 98 hygromycin-resistant, GUS-positive callus lines were transferred to MS-I medium containing $250 \mathrm{mg} \cdot \mathrm{L}^{-1}$ cefotaxime and $50 \mathrm{mg} \cdot \mathrm{L}^{-1}$ hygromycin. Twenty-two G418-resistant, GUS-positive callus lines were transferred to MS-I medium containing $250 \mathrm{mg} \cdot \mathrm{L}^{-1}$ cefotaxime and $50 \mathrm{mg} \cdot \mathrm{L}^{-1} \mathrm{G} 418$. Some globular embryo-like structures appeared in $\approx 1$ week. After 3 weeks, 50 hygromycin-resistant and 10 G418-resistant, GUS-positive, independent transgenic callus lines had developed numerous shoot primordia (Fig. 2E). Upon histochemical assay for expression of the GUS gene, $\approx 80 \%$ stained dark blue (Fig. 2F) indicating that GUS activity was not affected by shoot morphogenesis.

Green shoots and plantlets (10 to 20 from each transgenic line) that developed on MS-D media were transferred to MS-R medium to induce and facilitate root development. More than $90 \%$ of the shoots rooted readily and were transferred eventually to growing medium (Fig. 2G). About $80 \%$ to $90 \%$ of plants survived transfer to the greenhouse and developed into morphologically normal plants (Fig. 2H).

ANalyses of TRansgenic Plants. Putative transgenic plants were assayed for expression of the GUS and NPTII genes. A total of 92 plants from 36 independent lines were assayed for GUS activity. About $80 \%$ of those plants were GUS-positive (Table 1). Expression of the GUS gene was very strong in both leaves and roots, as judged by the intensity of staining in those tissues (Fig. 2J, $\mathrm{K}$, and $\mathrm{L}$ ).

Expression of the NPTII gene was assessed by a leaf-bleach assay in 60 transgenic plants from 33 independent lines. About $85 \%$ of those plants were resistant to paromomycin $\left(\mathrm{NPTII}^{+}\right)$(Table 1). Leaf samples from resistant transgenic plants remained green, except on the cut edges at higher paromomycin concentrations (Fig. 2I). The leaf samples from control (nontransgenic) plants, however, were almost completely bleached at $200 \mathrm{mg} \cdot \mathrm{L}^{-1}$ paromomycin.

In total, 58 plants from 26 independent lines were assayed for coexpression of the GUS and NPTII genes. About $78 \%$ of them coexpressed both genes (Table 1).

To demonstrate stable transformation of iris plants with the $h p t$ and GUS genes, four independent transgenic plants were subjected to Southern blot analysis. In pTOK233, the $h p t$ gene is located next to the left border of the T-DNA region. The first HindIII site inside the T-DNA from the left border cuts at the 3'-end of the of the $h p t$ cassette. Digestion of genomic DNA with HindIII, and subsequent hybridization with the $h p t$ probe for the coding sequence identifies border fragments between the integrated T-DNA and plant DNA, thus giving rise to different fragment lengths, depending on location of insertion in the genome. HindIII also cleaves the entire GUS coding region from the T-DNA as a $3.1 \mathrm{~kb}$ fragment. DNA blot analysis of HindIII-digested genomic DNA from our GUS-positive/ hygromycin-resistant plants, using the GUS probe, identified several banding patterns (Fig. 3A). Some of the samples (Fig. 3A, lanes 3 and 4 ) indicate the presence of a truncated GUS insert (i.e., inserted GUS cassette slightly smaller than expected). Additional bands with larger sizes may be due to incomplete digestion of genomic DNA or possibly deletion of the flanking HindIII site(s). Despite the GUS gene size polymorphisms, $\beta$-glucuronidase activity was readily detectable. The GUS probe did not hybridize to any DNA from nontransformed plants.

Stable integration of the $h p t$ gene into the iris genome was detected by a ${ }^{32} \mathrm{P}$-labeled DNA fragment from the coding region of the $h p t$ gene. Figure 3 (Panel B) illustrates examples of both single and multiple $h p t$ copy insertion into different loci of the iris nuclear

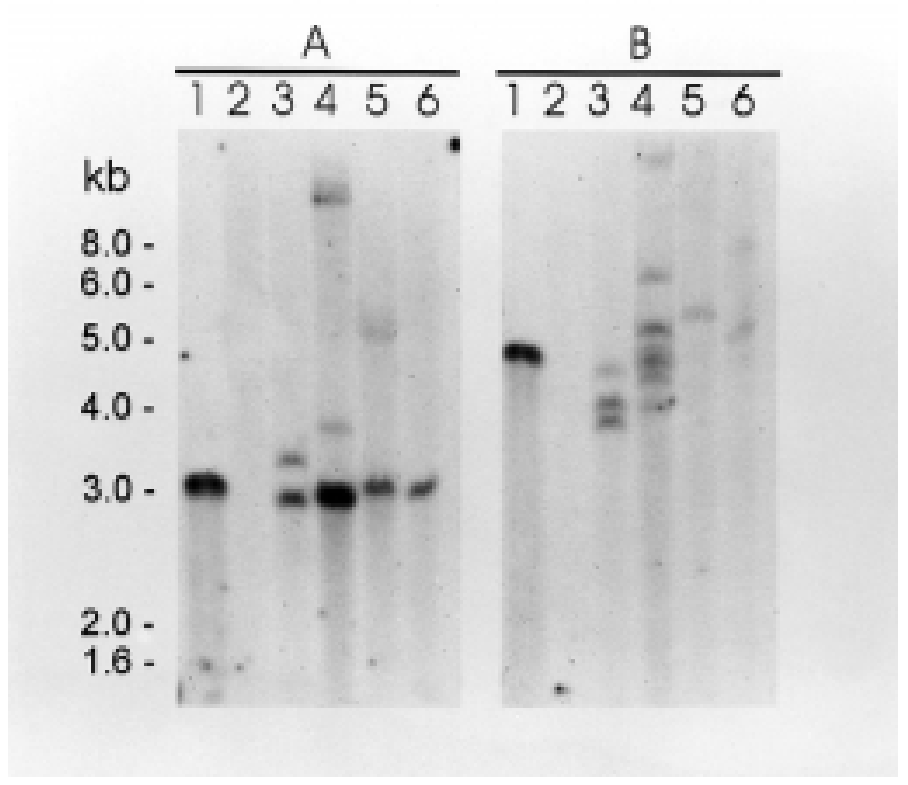

Fig. 3. Southern blot analysis of HindIII-digested genomic DNA from wild type (nontransformed) and transgenic iris plants. DNA blot probed with (A) ${ }^{32} \mathrm{P}$ labelled GUS or (B) hpt DNA fragment. Lane: 1, positive control (HindIIIdigested pTOK233); 2, nontransformed; 3 to 6 , transgenic plants: H177-1, H206-2, H231-05, and H244-1. 
genome. Some inserted hpt fragments (Fig. 3, Panel B, lanes 3 and 4) were smaller than the minimum expected size (4.8 kb; Fig. 3, Panel B, lane 1). Those smaller sized bands may be due to rearrangement in the integrated genes but none of the tested plants showed loss of tolerance to hygromycin. No hpt sequence was detected in the nontransformed sample.

We obtained over 300 putative transgenic plants in $\approx 6$ months. About $80 \%$ of tested plants were deemed transgenic based on GUSpositive staining and their antibiotic-resistant phenotype. The Southern blot data confirmed stable integration of the transgenes into the iris genome. GUS-positive and paromomycin-resistant phenotypes of those plants are indicative of the functional transgene expression. The CaMV35S promoter seems to be a strong promoter for iris plants, as indicated by the intensive color development during GUS staining. Thus, this promoter should be a good choice for the expression of gene(s) of interest in iris plants.

Our results confirmed that Agrobacterium-mediated transformation could be applied to horticulturally important monocotyledonous ornamentals, such as Iris. The newly developed Agrobacterium-mediated transformation method can be used to complement conventional breeding for improvement of Iris. Transferring genes from heterologous species provides a means of introducing new traits into the Iris L. genome, thus expanding the gene pool beyond what has been available in traditional iris breeding systems.

\section{Literature Cited}

Abedinia, M., R.J. Henry, A.B. Blakeney, and L. Lewin. 1997. An efficient transformation system for the Australian rice cultivar, Jarrah. Austral. J. Plant. Physiol. 24:133-141.

Arencibia, A.D., E.R. Carmona, P. Téllez, M-T. Chan, S-M. Yu, L.E. Trujillo, and P. Oramas. 1998. An efficient protocol for sugarcane (Saccharum sp. L.) transformation mediated by Agrobacterium tumefaciens. Transgenic Res. 7:213-222.

Arias-Garzón, D.I. and R. Sarria. 1995. New Agrobacterium tumefaciens plasmids for cassava transformation. Proc. 2nd Intl. Scientific Mtg. of The Cassava Biotechnol. Network. CIAT Working Doc. 150, 1:245-251.

Chen, F-C. and A.R. Kuehnle. 1996. Obtaining Transgenic Anthurium through Agrobacterium-mediated transformation of etiolated internodes. J. Amer. Soc. Hort. Sci. 121:47-51.

Cheng, M., J.E. Fry, S. Pang, H. Zhou, C.M. Hironaka, D.R. Duncan, T.W. Conner, and Y. Wan. 1997. Genetic transformation of wheat mediated by Agrobacterium tumefaciens. Plant Physiol. 115:971-980.

Chilton, M.D., T.C. Currier, S.K. Farrand, A.J. Bendich, M.P. Gordon, and E.W. Nester. 1974. DNA and PS8 bacteriophage DNA not detected in crown gall tumors. Proc. Natl. Acad. Sci. USA 71:3672-3676.

Conner, A.J. and E.M. Dommisse. 1992. Monocotyledonous plants as host for Agrobacterium. Intl. J. Plant. Sci. 153:550-555.

Davis, J., D. Henderson, M. Kobayashi, M.T. Clegg, and Michael T. Clegg. 1998. Genealogical relationship among cultivated avocado as revealed through RFLP analyses. J. Hered. 89:319-323.

Feinberg, A.P. and B. Vogelstein. 1983. A technique for radiolabelling DNA restriction endonuclease fragments to high specific activity. Anal. Biochem. 123:6-13.

Gould, J., M. Devey, O. Hasegawa, E.C. Ulian, G. Peterson, and R.H. Smith. 1991. Transformation of Zea mays L. using Agrobacterium tumefaciens and the shoot apex. Plant Physiol. 95:426-434.

Gozu, Y., M. Yokoyama, M. Nakamura, R. Namba, K. Yomogida, M. Yanagi, and S. Nakamura. 1993. In vitro propagation of Iris pallida. Plant Cell Rpt. 13:12-16.

Hiei, Y., S. Ohta, T. Komari, and T. Kumashiro. 1994. Efficient transformation of rice (Oryza sativa L.) mediated by Agrobacterium and sequence analysis of the boundaries of the T-DNA. Plant J. 6:271-282.

Hoekema, A., P.R. Hirsch, P.J.J. Hooykaas, and R.A. Schilperoort. 1983. A binary plant vector strategy based on separation of vir- and T-region of the Agrobacterium tumefaciens Ti-plasmid. Nature 303:179-180.

Hood, E.E., S.B. Gelvin, L.S. Melchers, and A. Hoekema. 1993. New Agrobacterium vectors for plant transformation. Transgenic Res. 2:208218.

Ishida, Y., H. Saito, S. Ohta, Y. Hiei, T. Komari, and T. Kumashiro. 1996. High efficiency transformation of maize (Zea mays L.) mediated by Agrobacterium tumefaciens. Nature Biotechnol. 14:745-750.

Jéhan, H., D. Courtois, C. Ehret, K. Lerch, and V. Petiard. 1994. Plant regeneration of Iris pallida Lam. and Iris germanica L. via somatic embryogenesis from leaves, apices and young flowers. Plant Cell Rpt. 13:671-675.

Kamo, K., A. Blowers, F. Smith, and J. Van Eck. 1995. Stable transformation of Gladiolus using suspension cell and callus. J. Amer. Soc. Hort. Sci. 120:347-352.

Kohlein, F. 1987. Iris. Timber Press, Portland, Ore.

Komari, T. 1990. Transformation of cultured cells of Chenopodium quinoa by binary vector that carry a fragment of DNA from the virulence region of pTiBo542. Plant Cell Rpt. 9:303-306.

Komari, T., Y.Hiei, Y.Ishida, T. Kumashiro, and T. Kubo. 1998. Advances in cereal gene transfer. Plant Biotechnol. 1:161-165.

Kuehnle, A.R. and N. Sugii. 1992. Transformation of Dendrobium orchid using particle bombardment of protocorms. Plant Cell Rpt. 11:484-488.

Li, H-Q., C. Sautter, I. Potrykus, and J. Puonti-Kaerlas. 1996. Genetic transformation of cassava (Manihotesculenta Crantz). Nature Biotechnol. 14:736-740.

Liu, C-N., X-Q. Li, and S.B. Gelvin. 1992. Multiple copies of virG enhance the transient transformation of celery, carrot, and rice tissues by Agrobacterium tumefaciens. Plant Mol. Biol. 20:1071-1087.

Murashige, T. and F. Skoog. 1962. A revised medium for rapid growth and bioassays with tobacco tissue cultures. Physiol. Plant. 15:473-497.

Ohta, S., S. Mita, T. Hattori, and K. Nakamura. 1990. Construction and expression in tobacco of a $\beta$-glucuronidase (GUS) reporter gene containing an intron within the coding sequence. Plant Cell Physiol. 31:805-813.

Rawson, J.R.Y., K. Thomas, and M.T. Clegg. 1982. Purification of total cellular DNA from a single plant. Biochem. Genet. 20:209-219.

Sambrook, J., E.F. Fritsch, and T. Maniatis. 1989. Molecular cloning: A laboratory manual. 2nd ed. Cold Spring Harbor Lab. Press. Plainview, N.Y.

Schrott, M. 1995. Selectable markers and reporter genes, p. 325-336. In: I. Potrykus and G. Spangenberg (eds.). Gene transfer to plants. SpringerVerlag, Berlin.

Smith, H.R. and E.E. Hood. 1995. Agrobacterium tumefaciens transformation of monocotyledons. Crop Sci. 35:301-309.

Tingay, S., D. McElroy, R. Kalla, S. Fieg, M. Wang, S. Thornton, and R. Brettell. 1997. Agrobacterium tumefaciens-mediated barley transformation. Plant J. 11:1369-1375.

Vain, P., J. De Buyser, V.B. Trang, R. Haicour, and Y. Henry. 1995. Foreign gene delivery into monocotyledonous species. Biotechnol. Adv. 13:653-671.

van Marrewijk, G.A.M. 1994. Prospects of biotechnology in horticultural breeding. Acta Hort. 369:199-219.

Waddick, J.W. and Y. Zhao. 1992. Iris of China. Timber Press, Portland, Ore.

Walkerpeach, C.R. and J. Velten. 1994. Agrobacterium-mediated gene transfer to plant cells: Cointegrate and binary vector systems. B1, p. 1-19. In: S.B. Gelvin and R.A. Schilperoort (eds.). Plant molecular biology manual. Kluwer Academic Publishers, Dordrecht, The Netherlands.

Wang, Y., Z. Jeknic, R.C. Ernst, and T.H.H. Chen. 1999a. Efficient plant regeneration from suspension-cultured cells of tall bearded iris. HortScience 34:730-735.

Wang, Y., Z. Jeknic, R.C. Ernst, and T.H.H. Chen. 1999b. Improved plant regeneration from suspension-cultured cells of Iris germanica L. 'Skating Party'. HortScience (in press).

Wenck, A.R., M. Quinn, R.W. Whetten, G. Pullman, and R. Sederoff. 1999. High-efficiency Agrobacterium-mediated transformation of Norway spruce (Picea abies) and loblolly pine (Pinus taeda). Plant Mol. Biol. 39:407-416. 